\title{
DIAGNÓSTICO DA MORTALIDADE DE PEDESTRES NOS ESTADOS BRASILEIROS: MODO DE TRANSPORTE
}

\author{
G. P. Caldeira' ${ }^{1}$ B. P. Branco ${ }^{1,2}$; J. T. Bastos ${ }^{1,3}$ \\ ${ }^{1}$ Universidade Federal do Paraná, Rua Evaristo F. F. da Costa, 418, Jd. das Américas, Curitiba/PR \\ ${ }^{2}$ Observatório Nacional de Segurança Viária, R. 9 de Julho, 1953, Vila Georgina, Indaiatuba \\ gabrielcaldeira@ufpr.br', beatriz.branco@onsv.org.br ${ }^{2}, j t b a s t o s @ u f p r . b r^{3}$
}

Resumo: Dado o cenário de mortalidade no trânsito com uma elevada participaçáo dos pedestres do total de mortes no trânsito no Brasil, esta pesquisa tem por objetivo analisar esta situação e construir um diagnóstico da mortalidade de pedestres nos estados brasileiros, com destaque para os contrastes regionais em relação ao veículo envolvido no atropelamento. Destacam-se duas categorias de veículos envolvidos nos atropelamentos: motocicleta no AC, AP e PI; e automóvel no AP, DF, GO, MS e RR.

Palavras-chave: Pedestres, Mortalidade, Estados brasileiros.

\section{Introdução}

As condiçốes de circulação para o pedestre no meio urbano são, em geral, precárias e não há uma rede de transporte a pé que garanta um nível de segurança e conveniência adequados $[1 ; 2]$. As viagens realizadas a pé representaram 36,5\% das viagens nas cidades em 2014 [3] - o que leva à necessidade de um diagnóstico da mortalidade dos pedestres nos estados.

\section{Metodologia}

A metodologia incluiu a coleta de dados secundários estaduais no período 2000-2015 referentes a mortes em atropelamentos (DATASUS) [4] e frota de veículos (DENATRAN) [5] e posterior análise comparativa dos dados.

\section{Resultados esperados/Conclusóes}

Em relação ao veículo envolvido no atropelamento, tem-se que no ano 2000 havia uma grande proporção de óbitos no qual o veículo "atropelador" foi classificado como "outros/não identificado" - em média, em 86\% dos casos. No ano de 2015 houve uma redução da média nacional deste valor para 56\%, o que viabilizou a realização das análises para os estados do AC, AP, DF, GO, MS, PI e $\mathrm{RR}$, que apresentaram proporçôes de óbitos com o veículo envolvido no atropelamento classificado como "outros/náo identificado" abaixo de 30\%. Dessa forma, duas categorias de veículos envolvidos nos atropelamentos sobressaem-se: motocicleta nos estados do AC, AP e PI - em média igual a 36\% 
de participação; e automóvel nos estados do AP, DF, GO, MS e RR - em média igual a 38\% de participação.

\section{Referências}

[1] GOLD, Philip (Brasil). Qualidade de Calçadas no Município de Sáo Paulo. São Paulo: Gold Projects, 2004.

[2] VASCONCELLOS, Eduardo Alcântara de. Políticas de Transporte no Brasil: A construção da mobilidade excludente. Barueri: Manole, 2014. 289 p.

[3] ASSOCIAÇÃO NACIONAL DE TRANSPORTES PÚBLICOS (ANTP) (Brasil) (Org.). Relatório Geral 2014. São Paulo, 2016. 96 p.

[4] BRASIL. Ministério da Saúde. Sistemas de Informaçôes de Mortalidade - DATASUS. Mortes por causas externas no período 2000-2015. Disponível em: <http://www2.datasus.gov.br/DATASUS>. Acesso em: 10 ago. 2017.

[5] BRASIL. Ministério das Cidades. Departamento Nacional de Trânsito - DENATRAN. Frota de veículos no período 2000-2015. Disponível em: <http://www.denatran.gov.br/frota.htm>. Acesso em: 10 ago. 2017. 